\title{
The effect of cancellous bone grafts on time to consolidation at osteotomy site following tibial tuberosity advancement in dogs
}

\section{Interferência do osso esponjoso na consolidação óssea do defeito resultante da osteotomia para avanço da tuberosidade tibial em cães}

\author{
Danilo Roberto Custódio Marques ${ }^{1 *}$; José Fernando Ibañez²; \\ Juliana Fonseca Monteiro3; Ana Carolina Valentim Hespanha ${ }^{3}$; \\ Mayara Eggert ${ }^{3}$; Amanda Becker ${ }^{3}$; Itallo Barros Freita ${ }^{4}$
}

\begin{abstract}
Rupture of the cranial cruciate ligament is the main cause of lameness in dogs. Several surgical techniques are used as a treatment, especially osteotomies, as the tibial tuberosity advancement (TTA). Recently new research are being conducted investigating ways to reduce bone healing time. Cancellous bone grafting is considered to be the gold standard method to speed healing due to its osteoinductive and osteoconductive properties. The aim of this study was to evaluate the effect of cancellous gone grafts on the time taken for consolidation at the osteotomy site in dogs undergoing TTA surgery. TTA surgery was performed in 19 stifles in which there was rupture of the cranial cruciate ligament and a tibial plateau angle less than 27 degrees. The cases were divided into two groups: dogs in the control group (C) had TTA only and for those in the study group (E) TTA was complimented with a cancellous bone graft. Serial radiographs were evaluated at 21 day intervals post-surgery and consolidation was confirmed by visual inspection by three observers (two radiologists and an orthopedic surgeon). There was no difference in consolidation time between Groups $\mathrm{C}$ and $\mathrm{E}$. The addition of cancellous bone grafting to the osteotomy did not influence time to consolidation in dogs undergoing TTA surgery.
\end{abstract}

Key words: Dog. Graft. Orthopedics. Bone repair.

\section{Resumo}

A ruptura do ligamento cruzado cranial é a principal causa de claudicação em cães. Várias técnicas cirúrgicas são utilizadas como tratamento, principalmente as osteotomias, como o avanço da tuberosidade tibial (TTA). Atualmente pesquisas estão sendo realizadas com o intuito de diminuir o tempo de consolidação óssea. O osso esponjoso é considerado enxerto ósseo padrão ouro devido seu poder osteoindutor e osteocondutor. O objetivo desse trabalho foi avaliar o tempo de consolidação óssea em cães com uso de osso esponjoso ou não em animais submetidos a cirurgia de TTA. Foram operados 19 joelhos com ruptura do ligamento cruzado cranial e ângulo platô tibial inferior a $27^{\circ}$, submetidos a cirurgia de avanço da tuberosidade tibial foram aleatoriamente separados em dois grupos: C (controle) e E (TTA mais osso esponjoso). A consolidação óssea foi confirmada por método visual (três observadores), sendo dois radiologistas e um ortopedista, que avaliaram radiografias seriadas dos membros operados com intervalos de 21 dias. Os grupos $\mathrm{C}$ e $\mathrm{E}$ não apresentaram diferenças estatísticas nos tempos de consolidação do defeito ósseo. Conclui-se que não houve interferência no tempo de consolidação com uso de osso esponjoso na falha da osteotomia após TTA.

Palavras-chave: Cães. Enxerto. Ortopedia. Reparo ósseo.

${ }^{1}$ M.e, Universidade Federal do Paraná, UFPR, Curitiba, PR, Brasil. E-mail: danilovetmarques@hotmail.com

2 Prof., UFPR, Curitiba, PR, Brasil. E-mail: ibanez@ibanez.net.br

${ }^{3}$ Discentes, Programa de Residência em Área Profissional da Saúde, Medicina Veterinária, UFPR, Curitiba, PR, Brasil. E-mail: juvetmonteiro@gmail.com; ana.hespanha@bol.com.br; may.eggert@yahoo.com.br; amandabecker@gmail.com

${ }^{4}$ Discente, Curso de Mestrado do Programa de Pós-Graduação em Ciências Veterinárias. UFPR, Curitiba, PR, Brasil. E-mail: itallobf@gmail.com

* Author for correspondence 


\section{Introducion}

Rupture of the cranial cruciate ligament (RLCCr) is the most common cause of lameness in dogs (LAMPMANN et al., 2003). The etiology of RLCC is still uncertain, but the main causes are: lymphocytic plasmacytic synovitis, trauma, large angle of the tibial plateau, hormonal disorders such as hypothyroidism, advancing age and obesity (COOK, 2010). Large breed dogs are most commonly affected (DUVAL et al., 1999).According to Guthrie et al. (2012) the cause is multifactorial.

Over a hundred techniques are described for the correction of instability caused by the rupture of the cranial cruciate ligament in dogs and these can be classified into: intracapsular, extracapsular and biomechanical correction techniques, known as osteotomies (SMITH, 2000).

The corrective osteotomies, modify the biomechanics of motion, thereby improving the distribution of forces and increasing the dynamic stability of the joint. The TTA procedure advances the tuberosity, and thus the patellar ligament, to maintain the angle made by the patellar ligament and the tibial plateau at $90^{\circ}$ or less. This neutralizes the cranial shear forces and hence negates the requirement for an intact cranial cruciate ligament (KIM et al., 2008).

Major complications of TTA surgery include fracture of the tibia, meniscal injuries, implant failure, lick granuloma, medial patellar luxation, septic arthritis and ostemyelitis; all of which require repeat surgery. Minor complications that do not require further surgical intervention include: nondisplaced fractures of the proximal fragment of the tibial crest, implant failure with no displacement, edema, bruising, skin dehiscence, inadequate calcification of the osteotomy and a poorly positioned cage (LAFAVER et al., 2007).

The cancellous bone autograft is considered the gold standard of autografts since it is biologically compatible and accelerates bone repair (ALIEVI et al., 2007, FREITAS et al., 2008). It has 2 properties that enhance bone repair (osteogenesis, osteoconductive and osteoinductive), it attracts cells to the site of the graft and facilitates the input capillaries and recipient bed of cells that will later differentiate into bone lineage cells (ANCHIETA, 2007).

The main advantages of cancellous bone autografting are its relative resistance to infection, rapid repair times, low-grade inflammatory reaction and good incorporation into the host tissues (GASSEN et al, 2008; KALIL et al, 2012.).

Complications associated with cancellous bone grafting increase patient morbidity and are the result of damage to adjacent structures, damage to the donor site, bruising, scarring, infection, lameness, pain, increased anesthetic and surgical time, graft resorption and insufficient graft volume to repair large bone defects (ALIEVI et al., 2007, FREITAS et al., 2008).

There are a number of suitable donor sites for TTA surgery grafts (DIAS, 2007; DIAS, 2008; BOUDRIEAU, 2011). Iglésias (2009) proposed the collection of cancellous bone from the proximal tibia after the TTA procedure, this is a practical option and does not require a new surgical access.

Guerrero et al. (2011) compared the use of autologous cancellous bone in osteotomy after TTA procedure, and found no statistical difference between groups. Furthermore, Bisgard et al. (2011) compared the use of autologous cancellous bone grafts with a new TTA design, and reported advantages of placing autologous cancellous bone in the TTA osteotomy site.

The aim of this study was to compare the time to consolidation of the osteotomy site following tibial tuberosity advancement surgery for correction of cranial cruciate ligament rupture in dogs, with and without the use of cancellous bone grafts. 


\section{Materials and Methods}

This study was approved by the Committee for Ethics of the Federal University of Paraná (UFPRPR), protocol no.018 / 2014.

The study included 19 adult dogs diagnosed with rupture of the cranial cruciate ligament (RLCCr) and treated at UFPR-PR Veterinary Hospital in Curitiba. Diagnosis was made using the cranial drawer test and tibial thrust test.

The animals were anesthetized by the anesthesiology service HV-UFPR for radiographic surgical planning. Medial-lateral projections were made with the stifle flexed to approximately 135 degrees, as recommended by Damur et al. (2005). From the radiographs the tibial plateau angle (PTA) and the angle of the slope of the medial tibial condyle relative to the mechanical axis of the tibia were measured, as described by Hoffmann et al.(2006). Radiography was also used to rule out bone abnormalities and evaluate the presence of degenerative joint disease (DJD). The degree of tibial advancement required and the size of the TTA plate were calculated as described by Hoffmann et al. (2006).

Animals in which the tibial plateau angle was less than 27 degrees were included in the study. Animals were excluded from the study if they had DJD, other concurrent diseases such as cancer, hypothyroidism or hyperadrenocorticism (which could interfere with bone healing), or if the physeal line was still evident. Owner consent was given for all animals to be included in the study

Tibial tuberosity advancement (TTA) surgery was performed on 19 knees. The animals were divided randomly, into two groups: Group C (control) in which TTA surgery was performed without filling of bone defects with graft and group E (graft) in which TTA surgery was performed and the bone defect was filled with cancellous bone harvested from the osteotomy site itself.

Prior to surgery blood tests (complete blood count and biochemistry (creatinine, urea, alkaline phosphatase, alanine aminotransferase, albumin and gamma glutamyl transferase)) were performed.

Surgery was performed as described by Tepic et al. (2002). A parapatellar medial approach was used, followed by medial arthrotomy and a subpatellar incision for inspection of the menisci with the aid of Gelpi and knee retractors respectively. Incisions were made in the joint capsule, medial parapatellar fibrocartilage, medial fascia and vastus muscle and cranial part of the Sartorius for inspection and treatment of the medial and lateral menisci when necessary. Damaged menisci were treated by removal of the flap or partial meniscectomy, depending on the severity of the injury. The joint capsule was partially sutured with polidioxanone wire in sultan suture pattern. Access to the tibial crest was by exposure of the tibial shaft by dissection of the soft tissues (elevation of the body of sartorius and the aponeurosis of the gracilis, semi-membranous and semitendinosus muscles), periosteal incision to expose the tibial crest and the osteotomy site was demarcated with a number 11 scalpel or with electrocautery. The osteotomy was performed using an oscillating saw. The appropriate TTA plate (Focus TM) was then attached to the tibia crest fragment and the crest advanced and anchored to the cage. The plate was fixed to the tibial diaphysis. In group $\mathrm{E}$ dogs cancellous bone was harvested from the tibia (metaphyseal region) with the aid of a curette on the osteotomy. Periosteum and subcutaneous tissues were closed with standard polidioxanone using Sutan and Zig-Zag patterns, respectively. The skin was closed with standard nylon Sutan or scalloped sutures.

Immediately postoperatively craniocaudal and mediolateral radiographs were obtained to evaluate the alignment and position of the implants. Cephalexin $30 \mathrm{mg} \mathrm{kg}^{-1}$ every 12 hours for 7 days, carprofen $2.2 \mathrm{mg} \mathrm{kg}^{-1}$ every 12 hours for 7 days, dipyrone, $25 \mathrm{mg} \mathrm{kg}^{-1}$ every 8 hours for 10 days, tramadol hydrochloride $2 \mathrm{mg} \mathrm{kg}^{-1}$ every 8 hours for 7 days were prescribed post-operatively and a protective collar was dispensed to prevent the 
removal of the stitches. After 10 days, the animals returned to HV-UFPR for removal of the stitches and orthopedic evaluation.

Radiographic studies were performed every 21 days after surgery to monitor bone healing in both groups. For monitoring and evaluation of consolidation, radiographic images, in DICOM format, were evaluated by three observers; two radiologists and an orthopedic surgeon who had not attended the surgery nor examine the animals. Observers were blinded to the study group of the cases. Radiographs were examined by the observers in OsiriX ${ }^{\mathrm{TM}}$ at $50 \%$ zoom. Each observer scored each radiograph as either fully consolidated or unconsolidated. Bone consolidation was recorded when $2 / 3$ observers agreed that consolidation was present. Kappa agreement among observers on radiographs was 0.87 .

The variables weight, age, right or left knees and healing time were analyzed by the Shapiro-Wilk test. The ANOVA test was used to evaluate weight and age, with the mean analyzed by Tukey test. The Kruskal Wallis test was used to evaluate the medians obtained by the groups with respect to the right and left knee variables and time of healing. All analysis set $\mathrm{p}<0.05$.

\section{Results}

There were no differences regarding average weight and age between groups, nor between the medians of variables right and left stifle. The distribution of breed, sex, age, weight, and affected limb in each group is detailed in Table 1. Only weight and age values were normally distributed. The other variables, right and left stifle and bone healing time showed non-normal distribution. Meniscal injury was present in $88.89 \%$ of Group C and $90 \%$ of group $\mathrm{E}$ - only dogs 2 and 7 had no medial meniscal injury. One animal in Group C (11.11\%) and 1 in Group E (10\%) developed mild edema and hematoma at the surgical site.

Table 1. Breed, sex, age, weight, affected limb and group allocation for animals included in the study to evaluate the effect of cancellous bone grafts on consolidation of the bone defect resulting from TTA surgery - Curitiba, 2016.

\begin{tabular}{lllllll}
\hline Dog & Breed & Sex & Age (years) & Weight (Kg) & Stifles & Group \\
\hline 1 & Boxer & Female & 10 & 50 & Right & C \\
2 & Golden retriever & Female & 1 & 40 & Right & C \\
3 & Labrador retriever & Male & 10 & 50 & Left & C \\
4 & Pit bull terrier & Female & 8 & 27 & Right & C \\
5 & Pit bull terrier & Female & 3.5 & 27.5 & Left & C \\
6 & Pit bull terrier & Female & 7.5 & 40.9 & Right & C \\
7 & Pit bull terrier & Male & 9 & 29.3 & Left & C \\
8 & Mixed breed dog & Female & 6 & 22.5 & Right & C \\
9 & Mixed breed dog & Male & 2 & 35.5 & Right & C \\
10 & Basset hound & Female & 10 & 11 & Right & E \\
11 & English Bulldog & Female & 6 & 24.4 & Left & E \\
12 & Labrador retriever & Male & 10 & 50 & Right & E \\
13 & Pit bull terrier & Female & 3 & 29.5 & Right & E \\
14 & Pit Bull terrier & Female & 2 & 24.5 & Left & E \\
15 & Pit Bull terrier & Male & 5 & 38.5 & Right & E \\
16 & Rottweiler & Male & 11 & 45.2 & Left & E \\
17 & Mixed breed dog & Male & 2 & 35.5 & Right & E \\
18 & Mixed breed dog & Female & 13 & 40.2 & Right & E \\
19 & Mixed breed dog & Male & 6 & 18.4 & Right & E \\
\hline
\end{tabular}


There was no statistical difference between time to consolidation in groups $\mathrm{C}$ and $\mathrm{E}(\mathrm{p}=0.05)$. Table 2 shows the time to consolidation for each animal in its respective group. In Figure 1 the bone healing time scatter chart observed per animal in group $\mathrm{C}$ and group E.

All animals were weight bearing on the operated limb soon after surgery.

Table 2. Bone consolidation time (days) in the control and study group from the study to evaluate the effect of cancellous bone on healing of the bone defect resulting from TTA surgery, assessed by the Shapiro-Wilk test - Curitiba, 2016.

\begin{tabular}{lll}
\hline Dog & Group C (control) & Group E (study) \\
\hline 1 & 84 & 84 \\
2 & 105 & 105 \\
3 & 105 & 105 \\
4 & 105 & 84 \\
5 & 84 & 105 \\
6 & 105 & 84 \\
7 & 105 & 63 \\
8 & 84 & 126 \\
9 & 84 & 105 \\
10 & & 105 \\
\hline
\end{tabular}

Figure 1. Bone healing time scatter chart observed per animal in group $C(n=9)$ group $E(n=10)$.

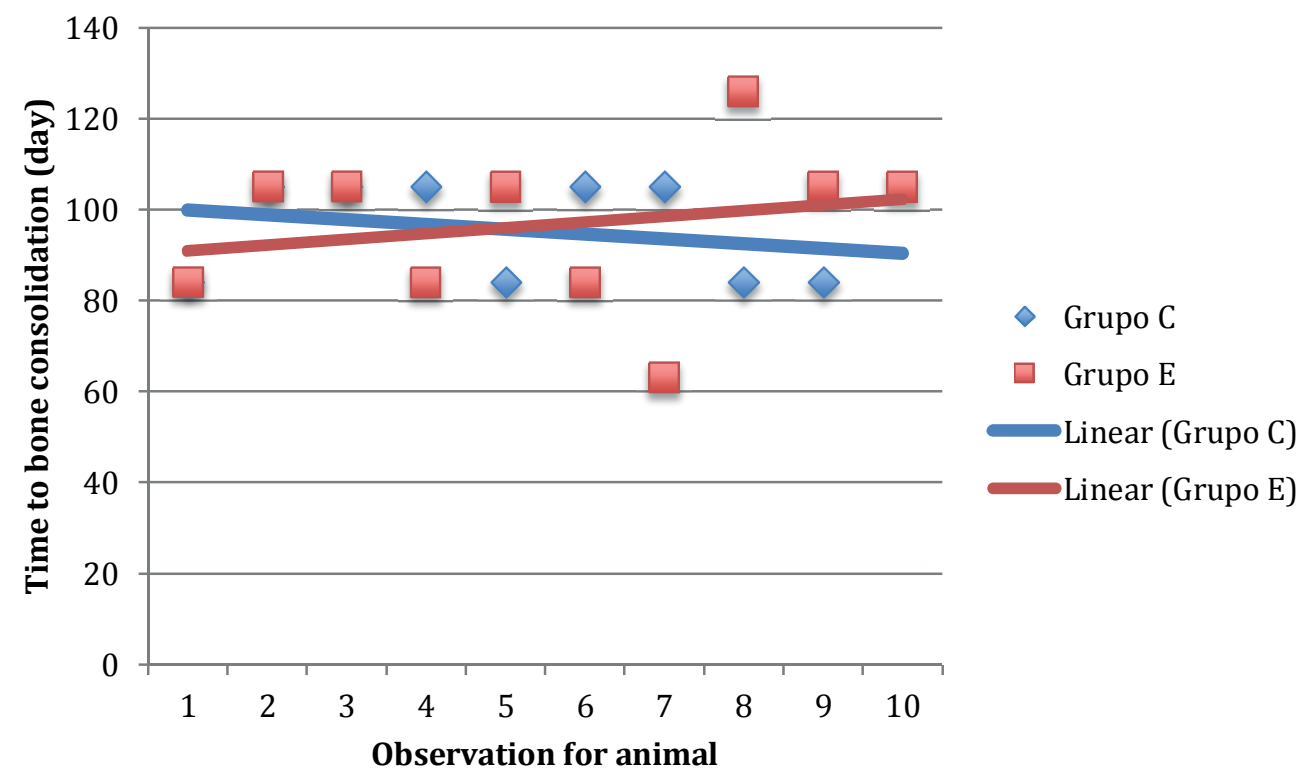

\section{Discussion}

Most dogs affected by RLCCr are large breeds, as reported by Fitzpatrick and Solano (2009). The breed most commonly represented in both Groups $\mathrm{C}$ and $\mathrm{E}$ was the pit bull terrier, and this breed is considered to be one of the four breeds most affected by RLCCr (GRIERSON et al, 2011; GUTHRIE et al, 2012.). Diagnosis of RLCCr was made with use of the cranial drawer and tibial thrust tests, which are pathognomonic for RLCCr in dogs (MUIR, 1997). 
In this study animals were included only if the angle of the lower tibial plateau was less than 27 degrees. Tibial tuberosity advancement surgery is most appropriate in joints where the PTA angle is less than 27 degrees, because the limited the advancement and size of the cage (BOUDRIEAU, 2009; KIM et al, 2008; VEZZONI, 2006).

No difference in meniscal injury was observed between the groups $-88.9 \%$ and $90 \%$ in group $\mathrm{C}$ and $\mathrm{E}$ respectively, these rates are higher than the $20-80 \%$ previously reported in the literature (GATINEAU et al, 2011; MOLES et al., 2009).

All meniscal injuries were in the medial meniscus, and this is reported to be a common injury in patients with RLCCr (BOUDRIEAU, 2007; KIM et al., 2008).

In this study we used a TTA plate instead of the blocked plate system. A 3 plate was using two screws, rather than the fork, to stabilize the tension band plate on the tibia crest. The advantages of tusing a TTA plate are that it is not necessary to rotate the tibial plateau, rather the angle is corrected by advancement alone, and a perfect contact between plate and bone is not required. Moreover, the plate results in fewer holes in the tibial crest, is easier to remove if the need arises and its placement requires less surgical time (BISGARD et al., 2011).

In this, as in other studies cancellous bone graft was collected from the region of the osteotomy (proximal metaphysis-epiphysis of the tibia) (STEIN; SHMOEKEL, 2008; VOSS et al., 2008). This method avoids new trauma, minimizes additional surgical and anesthetic time and reduces the risk of graft contamination (ALIEVI et al., 2007, FREITAS et al., 2008). Other authors have described the collection of cancellous bone from the osteotomy site, in an attempt to accelerate the process of consolidation of TTA (BISGARD et al., 2011; GUERRERO et al, 2011; IGLÉSIAS, 2009).

The osteotomy site for TTA is in the metaphyseal region of the tibia, which has a rich blood supply and a high concentration of cancellous bone
(GUERRERO et al., 2011), it would not apply the use of autogenous cancellous bone in the osteotomy for TTA, which is mainly used for comminuted fractures and extensive bone defects (DOREA et al., 2005). Thermal necrosis is a potential complication in TTA and was mininized by cooling with saline solution at the time of cutting. Griffon (2005) suggested that blood clots forming in the area of the osteotomy should be preserved to stimulate osteogenesis and bone tissue growth.

There was no statistical difference in time to consolidation between groups $\mathrm{C}$ and $\mathrm{E}$. Guerrero et al. (2011) reported that the use of cancellous grafting in TTA is unnecessary, because osteotomy healing times are similar in animals with or without grafts and stated that osteotomy consolidation following TTA was complete at around 90 days. In this study, full consolidation was apparent very close to that time.

The time to consolidation was determined visually by examination of radiographs. The same conditions were applied to both groups thus negating the effects of observer error when results from the 2 groups were compared. The method of visual analysis has been used in several studies to evaluate bone healing and is considered to be valid with high interobserver agreement (BOUDRIEAU, 2007; DANTES et al., 2016; ETCHEPAREBORDE et al, 2011; HOFFMANN et al., 2006).

The exact time of consolidation cannot be determined in this study because the radiographs were taken at 21 day intervals, according to protocol of Ibanez et al. (2003). However it would not be practical to radiograph patients more frequently. Studies have shown that there is limited value in performing radiographs at intervals of less than 21 days as this did not change the reported time to consolidation (LAFAVER et al., 2007; GUERRERO et al., 2011). Accurate completion of bone healing can only be determined histologically. We were not able to monitor time to bone healing using histopathology as the dogs in this study were clinical cases. 
One weakness of this study was that the amount of cancellous bone collected was not measured. The presence of cancellous bone in osteotomy was observed during the trans-operative. The ideal volume of cancellous bone for grafting has not been described and there are no studies that have identified a relationship between the size of the bone defect and optimal quantity of cancellous bone for grafting (KESSLER et al., 2005).

Minor complications were observed in $11.11 \%$ and $10 \%$ of animals in group $\mathrm{C}$ and $\mathrm{E}$, respectively. No major complication was observed in any patient in this study. In a study by Lafaver et al. (2007) complication rates of $12.3 \%$ major and $19.3 \%$ minor were reported.

\section{Conclusion}

The use of autogenous cancellous bone harvested from the metaphyseal region of the tibia, did not reduce the time to consolidation of the osteotomy site after tibial tuberosity advancement to correct rupture of the cranial cruciate ligament in dogs.

\section{References}

ALIEVI,M.M.; SCHOSSLER, J.E.W.; GUIMARÃES,L. D.; OLIVEIRA,A. N. C.; TRAESLEI, C. K.; FERREIRA, P. Implante ósseo cortical alógenoconservado em mel na reconstrução de falha óssea diafisária em fêmur de cães: avaliação clínica e radiográfica. Ciência Rural, Santa Maria, v. 37, n. 2, p. 450-457, 2007.

ANCHIETA, A. E. Enxerto ósseo autógeno intra-oral na implantodontia região pré-maxila.2007. (Monografia) UNORP/UNIPÓS,São José do Rio Preto.

BISGARD, S. K.; BARNHART, M. D.; SHIROMA, J. T.; KENNEDY, S. C.; SCHERTEL, E. R. The effect of cancellous autograft and novel plate design on radiographic healing and postoperative complications in tibial tuberosity advancement for cranial cruciate deficient canine stifles. Veterinary Surgery, Philadelphia, v. 40, n. 4, p. 402-407, 2011.

BOUDRIEAU, R. J. Letter to the editor: bone grafting and tibial tuberosity advancement. Veterinary Surgery, Philadelphia, v. 40, n. 5, p .641-643, 2011.
Tibial plateau leveling osteotomy or tibial tuberosity advancement? Veterinary Surgery, Philadelphia, v. 38, n. 1, p. 1-22, 2009.

LAFAVER, S.; MILLER, N. A.; STUBBS, W. P.; TAYLOR, R. A.; BOURIEAU, R. J. Tibial tuberosity advancement for stabilization of the canine cranial cruciate ligament deficient stifle joint: surgical technique, early results, and complication in 101 dogs. Veterinary Surgery, Philadelphia, v. 36, n. 6, p. 573-586, 2007.

COOK, J. L. Extracapsular stabilization. In: MUIR, P. Advances in the canine cranial cruciate ligament. Iowa: Wiley-Blackwell, 2010. cap. 24, p. 163-168.

DANTES, B. L.; SUL, R.; PARKIN, T.; CALVO, I. Incidence of complications associated with tibial tuberosity advancement in Boxer dogs. Veterinary and Comparative Orthopaedics and Traumatology, Stuttgart, v. 29, n. 1, p. 39-45, 2016.

DAMUR, D; GUERRERO, T.; MONTAVON, P. M.; TEPIC, S. Advancement of the tibial tuberosity for the treatment of cranial cruciate stifle: short guide for the operating room. Zurique: Clinic for Small Animal Surgery, Vetsuisse Faculty University of Zurich, 2005. p. 1-6.

DIAS, M. I.; LOURENÇO, P.; RODRIGUES, A.; AZEVEDO, J.; VEIGAS, C.; FERREIRA, A.; CABRITA, A. S. O efeito da quantidade do enxerto de osso esponjoso autólogo utilizado na regeneração óssea num modelo experimental de osteotomia da tíbia. Acta Médica Portuguesa, Porto, v. 20, n. 1, p. 37-46, 2007.

DIAS, F. A. C. Ruptura do ligamento cruzado cranial em canideos: avanço da tuberosidade tibial - estudo do ângulo do plateau em canídeos. 2008. (Dissertação de Mestrado em Medicina Veterinária) - Universidade Técnica de Lisboa, Lisboa.

DOREA, H. C.; MCLAUGHLIN, R. M.; CANTWELL, H. D.; READ, R.; ARMBRUST, L.; POOL, R.; ROUSH, J. L.; BOYLE, C. Evaluation of healing in feline femoral defects filled with cancellous autograft, cancellous allograft or bioglass. Veterinary and Comparative Orthopaedics Traumatology, Stuttgart, v. 18, n. 3, p. 157, 2005.

DUVAL, J. M.; BUDSBERG, S. C.; FLO, G. L.; SAMMARCO, J. L. Breed, sex, and body weight as risk factors for rupture of the cranial cruciate ligament in young dogs. Journal American Veterinary Medicine Association, Schaumburg, v. 215, n. 6, p. 811-814, 1999.

ETCHEPAREBORDE, S.; BRUNEL, L.; BOLLEN, G.; BALLIGAND, M. Preliminary experience of a modified Maquet technique for repair of cranial cruciate ligament 
rupture in dogs. Veterinary Comparative Orthopaedics and Traumatology, Philadelphia, v. 24, n. 3, p. 223-227, 2011.

FITZPATRICK, N.; SOLANO, M. A. Predictive variables for complications after TPLO with stifle inspection by arthrotomy in 1000 consecutive dogs. Veterinary Surgery, Philadelphia, v. 39, n. 4, p. 460-474, 2010.

FREITAS, S. H.; DÓRIA, R. G. S.; MENDONÇA, F. S.; EVÊNCIO NETO, J.; CAMARGO, L. M. Aspecto radiográfico de heteroenxerto ósseo cortical fragmentado na reparação de falhas ósseas em coelhos. Revista Brasileira Ciência Veterinária, Niterói v. 15, n. 3, p. 107 110, 2008.

GASSEN, H. T.; MUNER FILHO, R.; SIQUEIRA, B. M.; BOHM, S. O.; SILVA JUNIOR, N. A. Reconstrução óssea de maxila atrófica utilizando enxerto de ramo mandibular. Stomatos, Canoas, v. 14, n. 26, p. 55-63, 2008 .

GATINEAU, M.; DUPUIS, J.; PLANTÉ, J.; MOREAU, M. Retrospective study of 476 tibial plateau levelling osteotomy procedures. Veterinary and Comparative Orthopaedics Traumatology, Stuttgart, v. 24, n. 5, p. 333341, 2011.

GRIERSON, J.; ASHER, L.; GRAINGER, K. An investigation into risk factors for bilateral canine cruciate ligament rupture. Veterinary and Comparative Orthopaedics Traumatology, Stuttgart, v. 24, n. 3, p. 192196, 2011.

GRIFFON, D. Fracture healong. In: JOHNSON A. J.; HOULTON, J. E. F.; VANNINI, R. AO principles of fracture management in the dog and cat. Davos: $\mathrm{AO}$ Publishing, 2005. p. 73-97.

GUERRERO, T. G.; MAKARA, M. A.; KATIOFSKY, K.; FLUCKIGER, M. A.; MORGAN, J. P.; HAESSIG, M.; MONTAVON, P. M. Comparison of healing of the osteotomy gap after tibial tuberosity advancement with and without the use of autogenous cancellous bone graft. Veterinary Surgery, Hoboken, v. 40, n. 1, p. 27-33, 2011.

GUTHRIE, J. W.; KEELEY, B. J.; MADDOCK, E.; BRIGHT, S. R.; MAY, C. Effect of signalment on the presentation of canine patients suffering from cranial cruciate ligament disease. Journal of Small Animal Practice, Ontario, v. 53, n. 5, p. 273-277, 2012.

HOFFMANN, D. E.; MILLER, J. M.; OBER, C. P.; LANZ, O. I.; MARTIN, R. A.; SHIRES, P. K. Tibial tuberosity advancement in 65 canine stifles. Veterinary and Comparative Orthopaedics and Traumatology, Stuttgart, v. 29, n. 4, p. 219-227, 2006.
IBANEZ, J. F.; SILVA, T. S.; PONTES, D. R. Uso de decanoato de nandrolona (Deca-durabolinR) como estimulante da proliferação óssea em cães com consolidação retardada. Brazilian Journal of Veterinary Research and Animal Science, São Paulo, v. 40, n. 1, p. 229-230, 2003.

IGLÉSIAS, L. V. Comparação entre técnicas cirúrgicas para a correçãoo da ruptura do ligamento cruzado cranial em canídeos. 2009. (Dissertação de Mestrado em Medicina Veterinária) - Universidade Técnica de Lisboa, Lisboa.

KALIL, M. V.; CRUZ, L. M. M.; NASCIMENTO, A. G. S.; GRAÇA, N. J. F. Enxerto ósseo particulado aplicado à implantodontia. Revista Fluminense de Odontologia, Niterói, v. 2, n. 38, p. 33-38, 2012.

KESSLER, P.; THORWARTH, M.; BLOCHBIRKHOLZ, A.; NKENKE, E.; NEUKAM, F. W. Harvesting of bone from the iliac crest - comparison of the anterior and posterior sites. British Journal of Oral and Maxillofacial Surgery, Tokai City, v. 43, n. 1, p. 5156, 2005.

KIM, S. E.; POZZI, A.; KOWALESKI, M. P.; LEWIS, D. D. Tibial osteotomies for cranial cruciate ligament insuffi cient in dogs. Veterinary Surgery, Philadelphia, v. 37, n. 2, p. 111-125, 2008.

LAFAVER, S.; MILLER, N. A.; STUBBS, W. P.; TAYLOR, R. A.; BOUDRIEAU, R. J. Tibial tuberosity advancement for the stabilization of the canine cranial cruciate ligament-deficient stifle joint: Surgical technique, early results, and complications in 101 dogs. Veterinary Surgery, Philadelphia, v. 36, n. 6, p. 573-586, 2007.

LAMPMAN, T. J.; LUND, E. M.; LIPOWITZ, A. J. Cranial cruciate disease: current status of diagnosis, surgery, and risk for disease. Veterinary and Comparative Orthopaedics Traumatology, Stuttgart, v. 16, n. 3, p. 122126, 2003.

MOLES, A. D.; HILL, T. P.; GLYDE, M. Triple tibial osteotomy for treatment of the canine cranial cruciate ligament-deficient stifle joint. Surgical findings and postoperative complications in 97 stifles. Veterinary and Comparative Orthopaedics Traumatology, Stuttgart, v. 22, n. 6, p. 473-478, 2009.

MUIR, P. Physical examination of lame dogs. Compendium on Continuing Education for the Practicing Veterinarian, Califórnia, v. 19, n. 10, p. 1149-1161, 1997.

SMITH, B. Viewpoints in surgery cruciate ligament rupture, extracapsular stabilization. Australian Veterinary Journal, Victoria, v. 78, n. 6, p. 382-383, 2000. 
STEIN, S.; SCHMOEKEL, H. Short-term and eight to 12 months results of a tibial tuberosity advancement as treatment of canine cranial cruciate ligament damage. Journal of Small Animal Practice, Oxford, v. 49, n. 8, p. 398-404, 2008.

TEPIC, S.; DAMUR, D.; MONTAVON, P.M. Biomechanics of the stifle joint. In: WORLD ORTHOPAEDIC VETERINARY CONGRESS, 1., 2002, Munich. Proceedings... Munich: [s.n.], 2002, p. 189.
VEZZONI, A. Comparison of tibial plateau leveling osteotomy and tibial tuberosity advancement. In: WORLD VETERINARY ORTHOPAEDIC CONGRESS, 2., 2006, Keystone Proceedings... Keystone: Veterinary Orthopedic Society, 2006. p. 47-48.

VOSS, K.; DAMUR, D. M.; GUERRERO, T.; HAESSIG, M.; MONTAVON, P. M. Force plate gait analysis to assess limb function after tibial tuberosity advancement in dogs with cranial cruciate ligament disease. Veterinary and Comparative Orthopaedics Traumatology, Stuttgart, v. 21, n. 3, p. 243-249, 2008. 
